\title{
"High Tech" mimari
}

Arş. Gör. Özlem Eşsiz/Prof. Aydan Özgen

MSÜ Mimarlık Fakültesi, Yapı Bilgisi Anabilim Dalı.

\section{1. “High Tech” Tanımı}

1970'li yılların başında alternatif teknoloji olarak ortaya çıkan High Tech mimari, endüstride elektronik, bilgisayar, silikon çipler, robotlar anlamına gelirken, mimaride belirli bir stil/tarz anlamına gelmektedir (Davies,1991:6).

High Tech, son 20 yıl içinde Michael Hopkins, Nicholas Grimshaw, Richard Rogers ve Norman Foster'in tasarladıkları herhangi bir yapının etiketi olmuştur. Bu akımda yeralan mimarların hepsi İngiliz değildir, fakat yukarıda saydığımız aynı eğitimi almış bu dört İngiliz mimar bu akımın öncüleri sayılmaktadır (Davies,1991:6)..

High Tech mimaride, metal kutular ve makine görünümlü yapıların öne çıktığı görülmektedir. Kullanılan temel malzemenin metal ve cam oluşunun, büyük bir kullanış esnekliği getirmesinin yanında, teknolojik bir gösterime dönüşmesi kişileri etkilemekte ve bu yapıları şehirsel simgeler haline getirmektedir. High Tech yapılarının mimarları, mimarlığı endüstriyel tasarımın bir dalı olarak görmektedirler ve Le Corbusier'nin Evi "yaşam için bir makine" olarak tanımlaması bazında binaya bir makine olarak bakarak, kaynağı teknoloji ve hayal gücü olan binalar yapmaktadırlar.

Daha ileri giderek binayı günlük hayatta kullanılan bir alet olarak ele alıp, binaların fonksiyonel ve kullanışlı olması gerekti-ğini vurgularlar. Oysa burada bir çelişki ortaya çıkmaktadır. Daha basit bir yolla kullanışlı binalar yapmak mümkünken, tüm High Tech mimarlar büyük bir teknoloji gösterisi sergilemektedir. Çünkü bu mimarlar artık alışılagelmiş masif ve hantal binalarla, kesin bir ölçü vermeyen, beton, tuğla, harç, kereste gibi geleneksel malzemelerle uğraşmak istememektedirler. Fabrikada üretilmiş, kesin ölçülü cam ve metal gibi 1şıklı malzemeler ve kolay biraraya gelebilen parçaları tercih etmektedirler. Yapılar genellikle çelik kafes, hafif metal panel ve görülebilir servis kabuğu gibi karakteristik özellikler taşımaktadır. High Tech yapı örneklerinin daha çok fabrika, ofis, süpermarket, sanat ve sosyal binalarda uygulandığ görülmektedir (Türel, 1995:284).
Özet:

Yapı ve yapım alanındaki teknolojik gelişmeler, yeni yapı sistemleri, yeni yapım teknikleri ve yeni malzeme olanakların da beraberinde getirmektedir. Bu çalışmanın amacı High Tech kavramını açıklamak ve High Tech uygulamaların ortak ve temel özelliklerini saptamaktır.

High Tech, 1970'li yıllarda İngiltere'de doğmuş ve gelişmiştir. Özellikle İngiliz mimarlardan Richard Rogers, Michael Hopkins, Norman Foster, Nicholas Grimshaw ve Ian Ritchie bu akımın öncüleridir. Uyguladıkları mimari, makina estetiği kavramını ortaya koymak, cam ve çelik gibi endüstri devriminin malzemelerine ağırlık vermektir. Günümüzde bu yapıların yapımının yaygınlaşmasının başlıca nedenleri, taşıyıc strüktürün, tesisat sistemlerinin değișen teknoloji karşısında kendini yenilemesi, prestij yapılarının anıtsal bir özellik kazanmasıdır.

Bu bağlamda, günümüzde giderek artan uygulamalarıyla karşılaştığımız High Tech yapılar kullanıcılara üstün konfor koşulları sağlamakta ve kendini de günün koşullarına kolayca adapte edebilmektedir.

$\mathrm{Bu}$ çalışmada çağımızın ve giderek geleceğin yaygın yapıları olacak High Tech yapılar incelenmiş, özellikleri ve yapım sistemleri araştırılmıştır.

Summary:

The technological development in building and construction area, bring with the new construction systems and the new products. The aim of this study is to define the High Tech concept, and set the common and basic characteristics of High Tech applications.

During 1970's High Tech was born and developed in Britain. Especially British Architects Richard Rogers, Michael Hopkins, Norman Foster, Nicholas Grimshaw and Ian Ritchie are the leaders of this style. Their architecture show the machine aesthetic and use of industrial revoluation materials such as glass and steel. The reasons for wide usage of this technology in building constructions are, the ease of renewing the structural and installation systems by the changing technology and giving monumentality to the prestige buildings.

High Tech building which we have many examples of give their occupants a lot of opportunities and also they can adapt itself to the time.

Anahtar Kelimeler:

Estetik, High Tech Teknoloji, Tesisat Sistemi, Strüktürel Sistem

Keywords:

Aesthetics, High Tech Technology, Installation Systems, Structural System 

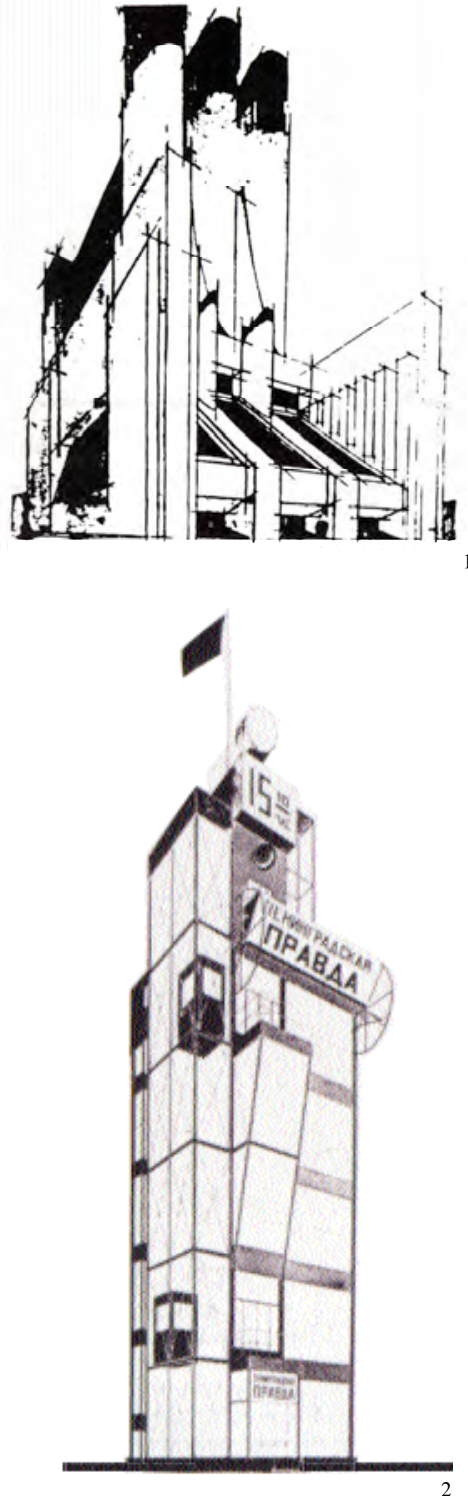

Şekil: I

Citta Nuova eskizi, Sant'Elia, 1914 Şekil: 2

Alexandr Vesnin'in bir eskizi, 1923 Şekil: 3

Chernikov'un bir eskizi, 1930

\subsection{High Tech'in Kısa Tarihi}

High Tech yapıların gelişimi 1970'lerin başına uzanan kısa dönem veya 19. Yüzyıl Endüstri Devrimi'ne uzanan uzun dönem olarak iki tarihî perspektifte incelenebilir. Uzun dönemde, 1779' da Coalbrookdale' deki Severn Nehri'ni geçen ilk dökme demir (cast iron) köprü tamamen metal prefabrike elemanlardan oluşarak ilk High Tech yapı ünvanını almıştır. 1848'de Decimus Burton'un Kew Garden'da Palm House'u, Paxton'un 1851'de yaptığ 1 Crystal Palace, Paris Sergisi için 1889'da yapılan Eiffel Kulesi, Contamin ve Dutert tarafından yapılan Galerie des Machines, gibi yapılar, geleneksel mimariden çok endüstriyel teknolojiyi kendilerine esas

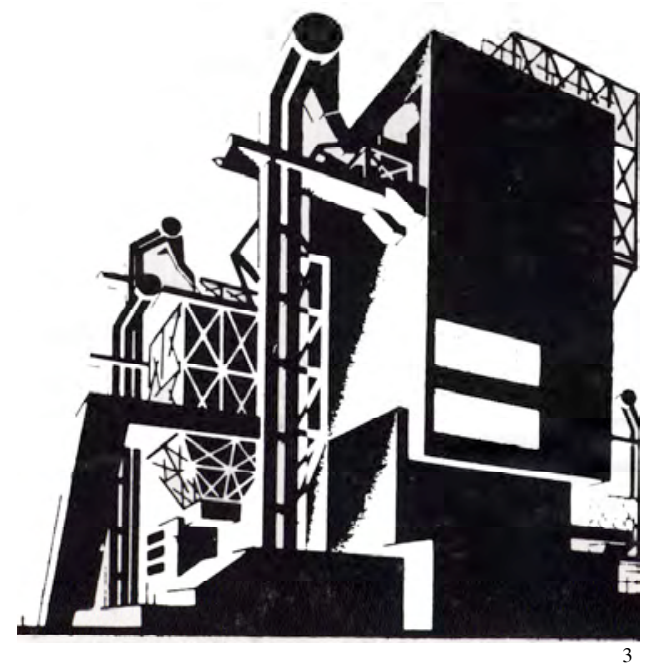

almışlar ve alternatif bir yapı tarzını temsil ederek bugünün High Tech mimarlarını etkilemişlerdir (Davies,1991:6).

Teorik projeler içinde de İtalyan futuristler ve Rus konstrüktüvistler dikkati çekmektedir. 1914'de Sant'Elia'nın Citta Nuova eskizi (Şekil 1) dış cepheye etkili bir görünüş kazandıran asansör kuleleri, kiriş köprüleri, yükseltilmiş yürüme yollarıyla Rogers'ın yapılarında da olduğu gibi High Tech'in heykelsi özelliğini taşımaktadır. Chernikov, Alexandr Vesnin gibi Rus konstrüktivistlerin çalışmalarında ise (Şekil 2-3)
High Tech'in motifleri olan diyagonal çelik bağlantılar, cam şaftlarda asansörler görülmektedir. Diğer yandan 1927'de Atlantiğin karşı yakasında Buckminster Fuller' in Dymaxion Evi hafif metal ve plastik altıgen strüktürün, mekânik servis çekirdeğine asılmasıyla oluşturulmuş bir High Tech uygulaması olarak karşımıza çıkmaktadır. Eğer biri "High Tech'in Babası" ünvanını hakediyorsa o da, uçak endüstrisinde kullanılan teknoloji ve malzemelerini kullanarak Dymaxion Evi projesini tasarlayan Fuller olmalıdır (Şekil 4).

30 yıllık kısa geçmişe bakıldığında ise, ilk İngiliz High Tech binası, 1967'de Swindon' da yapılan, basit strüktürlü Reliance Electronic Control Fabrikası'dır. Bu bina 1967'de, “En İyi Endüstriyel Bina" (Financial Times) ödülünü kazanmıştır. Tasarımcılarına bu yeni tarzı/stili geliştirmeleri için güven/enerji veren bu yapı, bir süre birlikte çalışan Foster ve Rogers'ın birlikte yaptıkları son yapı olmuştur. 1967 yılında Nicholas Grimshaw'ın tasarladığı öğrenci yurdunda, cam cephe arkasındaki gizli banyoların öne çıkarılmasıyla, High Tech'in motiflerinden biri olan servislerin dışarıdan algılanması fikri ortaya çıkmıştır. 1960'larda Londra mimarlık okullarında, özellikle Regent Street Polytechnic ve Architectural Association'da (AA) bir kısım hocalar ve öğrenciler bu doğrultuda çalışmalar yapmışlardır. Peter Cook, Warren Chalk, David Green, Denis Crompton, Ron Herron ve Mike Webb'den oluşan ARCHIGGAM grubunu (AA) oluşturmuş, 1970'lerde ve 1980'lerde High Tech mimarlığın özelliklerini yansıtan yayın ve sergiler düzenlenmiş; kitle üretimsel, pazarlanabilir hazır bileşenler ile uçak endüstrisi benzeri teknolojilerin bina alanında deneme çalışmalarını yapmışlardır (Kulaksızoğlu, 1995: 323-324). 
1970'de Rogers, Renzo Piano ile çalışmaya başlamış 1971'de girdikleri yarışmada Paris'te Plateau Beaubourg'da Uluslararası Kültür ve Sanat Merkezi proje yarışmasını kazanarak, tamamen esnek planlı, hücre ve makina teknolojisinin zaferi olarak High Tech'i günümüze getiren Centre Pompidou'yu 1977'de tamamlayarak birdenbire High Tech'in odak noktası olmasına imzalarını atmışlardır.

1920’lerin modernist öncüleri gibi High Tech'in öncüleri de, bu tarzın "çağın ruhu" olduğuna inanan ve bu ruhu yapılarında vurgulamayı kendilerine görev edinmiş kişilerdi. Geleneksel yapılarda kullanılan tuğla duvarların yapımının hızlı ve ucuz olmasına karşılık, teknolojiyi yakalamayı ve yapılarını 21. Yüzyıl'a taşımayı hedefleyen ve çağın ruhunun ileri teknolojide bulunduğuna inanan High Tech mimarları, günümüzün teknolojik malzemeleri olan, çelik çerçeveleri ve hafif metal panelleri tercih etmektedirler. Bilimsel ve endüstriyel teknolojide kaydedilen gelişmeler, çağımızın yüksek teknoloji çağı olarak kabul edilmesini gerektirmektedir. Günümüzün endüstriyel kültürünün ürünü olabilecek bir yapı da ancak bu teknolojileri kullanarak üretildiğinde çağın ruhunu yakalayacaktır. Bu nedenle bir yapının High Tech yapısı olabilmesi için teknik donatı, teknik süreç ve teknik kuramlar açısından High Tech bilinci ile tasarlanmış ve yapılmış olması gerekir. Çağın ruhunun yakalanmasının bir diğer koşulu da kamusal duyarlılıktır.

Geleceğe inancı tam olan, yeni ve daha iyi bir dünya kurulacağına inanan High Tech mimarları, tarihe gönderme yapan bir mimarlıktan yana olmayacaklarına inanırlar (Çağlar, Utkutuğ, 1995: 315-316).

\subsection{Seri Üretim Problemi}

Arabaların milyonlarcası üretilirken binalar sadece bir tane yapılmaktadır. Bir arabayı tasarlamak ve geliştirmek uzun zaman almakta, birçok prototipinin yapılması ve test edilmesi gerekmektedir. Eğer bir bina da aynı teknoloji ile yapılacaksa, aynı tasarım ve gelişim evrelerini izlemesi gerekmektedir; fakat aynı binadan binlerce üretilmedikçe bu mümkün olamayacaktır. Bunun yerine yapı bileşenleri, pencereler, kapılar, dikmeler, yükseltilmiş döşemeler ve asma tavanlar, fabrikalarda standart boyutlarda üretilmekte, bu olgu giderek binanın tüm bileşenlerinde yaygın hale gelmektedir. High Tech mimarları, seri üretim ve makinaya benzer bir mimari yaratarak, binaları geleneksel yapılara döndürmek yerine yeni bir çizgiye taşımak istemektedirler. Fakat High Tech'in kalbi sayılan İngiltere seri üretim ve ürünlerini kullanmaya bir direnç göstermektedir. Bunun nedeni bu sistemlerin donuk, fakir görünüşler oluşturmasıdır. Bu estetik problemi çözmenin bir yolu bileşen sistemini geliştirmektir. High Tech mimarları bunun için yeni detaylar geliştirmiştir. Bunların en iyi örneği, Norman Foster'ın Hong Kong Bankası'nda görülmektedir. Binanın temel elemanları; perde duvarsistemi, tavanlar, bölücü duvarlar, mobilyalar, döşemeler, servis modülleri, mimar ve üreticinin birlikte çalışmasıyla tasarlanmış, test edilmiş ve geliştirilmiştir. Yapının birçok bileşeni, değişik ülkelerde yapılmış ve inşaat alanına getirilmiştir (Jencks, 1990:91-94).

High Tech yapıların taşıyıcı sistemleri çoğunlukla yapının kenarına çekilerek, iç mekânların olabildiğince esnek tasarlanabilmeleri sağlanmıştır. Bu sayede yapı, zaman gereklerine göre istenen biçimde değiştirilebilmektedir. Taşıyıcı elemanlar-

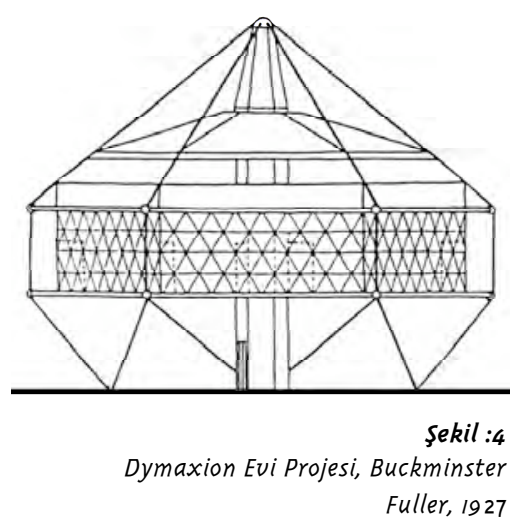



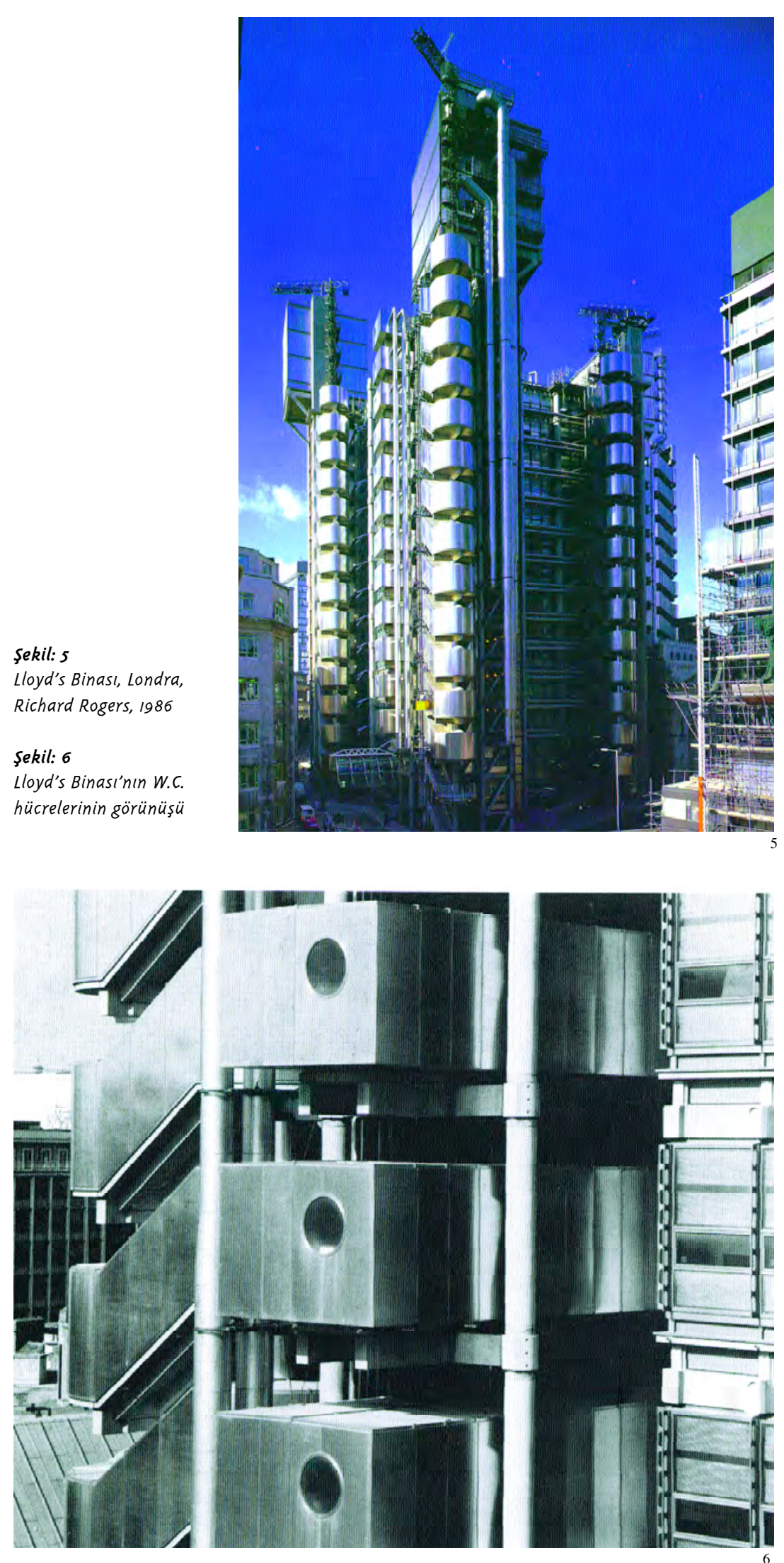

dan arındırılmış büyük mekânlar fikri, doğal olarak büyük açıklıkların geçilebilmesini gerektirdiğinden çelik, bu tür yapıların vazgeçilmez malzemesi olmuştur. Ancak, ileri teknoloji yapılarının birçoğu genellikle prestij yapıları olduğundan, mimari anlatım vuruculuğu ve gösteriş uğruna, ekonomik verimlilik ve rasyonalite gibi kriterler gözardı edilmektedir. Hatta özellikle finans kesiminden müşterilerin mimardan temel beklentisi bu yönde olmaktadır. Bu yaklaşımla, istenilen görsel etkiyi sağlayabilmek için abartılı denebilecek taşıyıcı sistem tasarımları yapılmıştır (Ökten, 1995: 299).

\subsection{Tesisat ve Hücre Sistemler}

Lloyd's Binası'nda, servisler, tesisat boruları ve taşıyıcı sistem, yapının dışına alınmış, bu şekilde açık mekânlar elde edilmiştir (Şekil 5). İlk hücre sistem 1937'de Buckminster Fuller'in tasarladı ğ çelik prefabrike Dymaxion banyosudur. Grimshaw'ın endüstriyel yapılarda kullanılabilecek, seri üretime uygun çelikten tasarladığ gelişiminde önderlik etmiştir. Kisho Kurokawa bunu daha ileri götürmüş, 1972’de Nagakin Kapsül Kulesi'nde hücre sistemini sadece banyolarda değil bütün yapıda kullanmıştır. Peter Cook'un 1964'de tasarladığ 1 Plug-in-City projesinde tüm şehri, hücre modüllerini ayakkabı kutuları gibi üst üste yerleştirerek oluşturması hücre sistemini şehir ölçeğine taşımak açısından dikkat çekicidir.

En dikkat çekici High Tech yapıları olan Lloyds Binası ve Hong Kong Bankası'nda da hücreler kullanılmıştır. Tuvaletleri (Şekil 6) içeren bu hücreler, şimdiye kadar yapılmış en etkili uygulamalardır. Aynı işlevi gören Hong Kong Bankası'ndaki hücreler ise fonksiyon ve etki bakımından 
Lloyds'dan farklıdır. Lloyds'daki hücreler yenileri ile değiştirilebilir şekilde düzenlenmiştir ve dışarıdan bakıldı ğında her hücre tekil olarak algılanabilmektedir. Hong Kong Bankası'nda ise hücreler devamlı cephe kaplamalarıyla giydirilmiş olduğundan dışardan bakıldığında hücre gibi gözükmemektedir (Eşsiz,1997:10). Bu hücrelerin yenilenebilir olmaları yanında, yapım hızını arttırmaları, ürünün bitmiş olması nedeniyle kalitenin yüksek olması ve mekanik tesisatlarına kolay ulaşım gibi birçok avantajı bulunmaktadır.

\section{High Tech Yapıların Ortak $\ddot{O}_{z e l l i k l e r i}$}

High Tech yapıların ortak özellikleri;

1. Esneklik (dış duvarda, çatıda, taşıyıcı iskelet sisteminde),

2. Saydamlık,

3. Parlak ve düz renklendirme,

4. İnce kablolar,

5. Cam, metal ve plastik malzemeler,

6. Strüktür ve servislerin algılanması, olarak sayılabilir. Bu temel özelliklerin yanısıra; enerji tasarrufu, sağlıklı hava ve gaz temizleme sistemi, doğal 1 şık kullanımı, aktif ve pasif kontrol mekanizmaları ile deprem ve rüzgârdan koruma sistemleri bu tür yapılarda görülmektedir (Jencks, 1988:270-289)

\subsection{Esneklik}

Esneklik, bir bütün olarak High Tech'e ait bir düşüncedir, ancak sözcük anlamıyla uyarlanabilme, parçaları sabit olsa bile uygulama gerekliliklerine göre özgürce ilişkilendirilebilen bir nesne düşüncesinin tersine, Modern Mimarlığgn geliştirdiği ayrı akımlardan biri olmuştur. Değişen ögeler kullanıcının değiştireceği türden olmakla kalmamalı, tasarımın sabit ögelerinden bağımsız bir biçimde de görülmelidir. Taşıyıcı, yapının genelliğini ve okunabilirliğini bozmadan istenildiği gibi yeniden düzenlenebilmelidir. Birçok ofis binasında, hareketli bölücü duvarlarla esneklik sağlanmıştır. High Tech'te ise bunun ötesine gidilmiştir; bu yapılarda dış duvarlar çatılar ve strüktürel çerçeve dahi hareketli olabilmektedir. Yapı elemanlarının tespitleri kuru birleşimlerle yapıldığından, aynı planda çok değişik fonksiyonlar oluşturulabilmesine imkân tanımaktadır. Centre Pompidou, Hong Kong Bankası ve Lloyd's Binası tamamlanmamış gibi görünmekte, bu nedenle de döşemeler ve diğer elemanlar strüktüre eklenebilme veya çıkartılabilme olanağına sahip bulunmaktadır. Her 15-20 yılda bir değiştirilmesi veya tamiri gerekecek servisler, tesisat boruları, asansör motorları, vb gibi elemanların yapının dışına alınması, bakım işlemlerini kolaylaştırmaktadır (Jencks, 1990: 91-94).

\subsection{Saydamlik}

Yarı saydam ve saydam cam borular, merdivenler, yürüyen merdivenler, asansörler High Tech yapıların belirgin özellikleridir. Lloyd's ve Hong Kong Bankası'nda

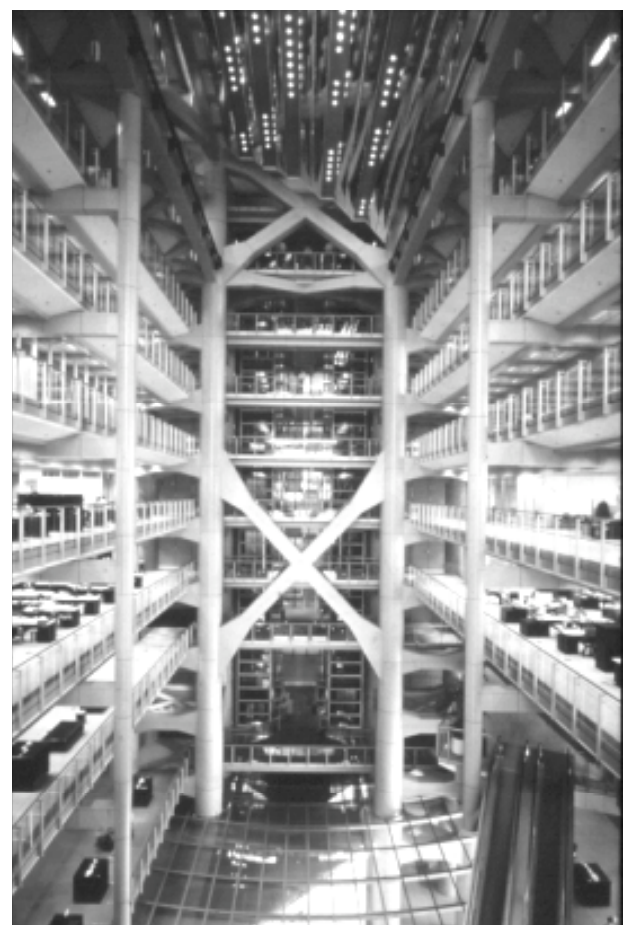

Şekil: 7

Hong Kong Bankasinnin if görünüşü 
yürüyen merdivenlerin mekanizmalarının görünmesi ve mekândan algılanması çalışanlara ve müşterilere büyük keyif vermektedir (Şekil 7). Çerçeve genel olarak narin bir ağ dokusu olarak dişa vurulmuş ve hem diş duvarlar hem iç bölücüler hafif ve geçici olarak ele alınmıştır.

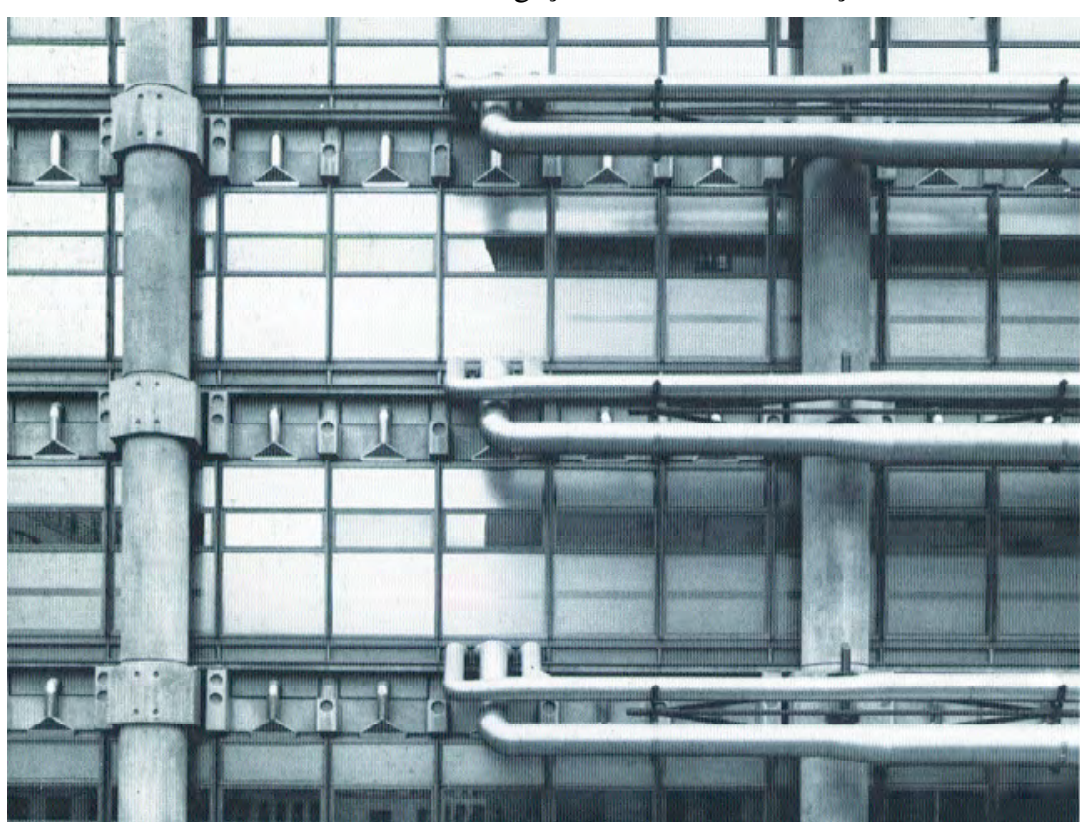

Şekil: 8

Lloyd's Binasinin tesisat kanallarının diş cepheden görünüşü

\subsection{Parlak ve Düz Renklendirme}

Centre Pompidou ve Inmos'ta Rogers'in, parlak renkler kullandığı gibi, High Tech yapılarda değişik strüktür elemanlarının ve servislerin, kullanılan bu renkler sayesinde kolayca algılanabilmesi sağlanmıştır.

Parlak sarı, kırmızı ve maviler endüstri makinalarının renkleri olarak, High Tech yapılarda da kullanılmaktadır. Son çalışmalarında Rogers ve Foster gümüş estetiğine doğru kaymış, strüktürü, boruları, gri tonlarıyla bütünleştirmiştir (Russel, 1985:125-130).

\subsection{Ince Kablolar}

İnce çelik çapraz kablolar (rüzgâr gergileri) High Tech'in dorik kolonlarıdır. Foster ve Rogers'in 1967'de yaptıkları Reliance Control Building'de bu özellikler görülmektedir.

\subsection{Cam, Metal ve Plastik Malzemeler}

Daha önce değinildiği gibi Le Corbusier, konutları "içinde yaşanılan birer makina" olarak tanımlamış fakat yaptığ 1 yapılarda teknolojiyi öncelikli olarak kullanmasına rağmen bu binaları hiç de makinaya benzetmemiştir. High Tech yapıların referansı olan makinalar, ister hareketli ister sabit olsun karmaşık yapıdadırlar ve daha çok cam, metal, plastik gibi sentetik maddeler içermektedirler.

\subsection{Strüktür ve Servislerin Algılanması}

Genelde dişarıdan görülebilen strüktür ve servisler High Tech mimarinin en önemli, gözle görülen özelliğini oluşturur. Tesisat kanalları ve boruları binanın dişına alınmakta ya da çok kolay ulaşılabilir bir biçimde düzenlenmektedir. Bu sayede bir değişiklik gerekli olduğu zaman bu iş, binanın işlevini aksatmadan kolayca yapılabildiği gibi bakım ve onarım eylemleri de aynı kolaylık ve düzen içinde gerçekleştirilebilmektedir (Şekil 8). High Tech'in iki öncüsü Norman Foster ve Richard Rogers arasındaki önemli tarz farkı, her ikisinin yapı içindeki servisleri kullanış şekilleridir. Rogers yapılarındaki tüm tesisat sistemlerinin dışarıdan algılanmasına, arıza anında kolaylıkla ulaşılabilir yerlerde olmasına dikkati çekerek tasarımlarını yaparken, Foster ise servis boruları ile, kanalları, asma tavan veya yükseltilmiş döşemeye gizlemeyi tercih etmektedir.

\section{High Tech Yapıların Diğer Özellikleri 3.1. Enerji Tasarrufu}

20. Yüzyıl her alanda olduğu gibi, yapı teknolojisinin de büyük gelişimine sahne oldu ve buna paralel olarak, kullanıcıların yapıda konfor ve güvenlik beklentileri arttı. 1960'lara doğru yapıların nitelikleri, kullanım tarzları ve yapılarda kullanılan sistemler o kadar gelişmişti ki, artık 
yapının 1sıtma, soğutma ve 1şıklandırma ihtiyacı, mekanik ve elektrik sistemler ile karşılanıp, mühendislerin sorumluluğunda uygulanmaktaydı. Bu yıllarda, özellikle Batı ülkelerinde, mühendisliğin zaferi olarak tanımlanan yüksek, büyük, geniş, korkutucu boyutlarda enerji harcayan mekanik sistemler ile donatılmış yapılar inşa edildiğini gözlemlemekteyiz.

1970’lerdeki enerji krizi ile birlikte ister istemez, yeni bir anlayış gelişti. Yapılarda, sadece mekanik sistemler ile değil, ancak mekanik sistem çözümleri ile yapının kendi tasarımının birleşimi sayesinde, konforun verimli bir biçimde sağlanabileceği fikri kabul görmeye başladı. 1980'lerden itibaren ise, mimari tasarımların mekanik ve elektrik uzmanlık alanları ile entegrasyon ihtiyacı ve bu doğrultuda gelişimi, "yapı teknolojisi" biliminin ayrı bir uzmanlık dalı olarak ortaya çıkmasına yol açtı.

Günümüzde yapının sadece 1sitılması, soğutulması ve 1şıklandırılması yetmemektedir. Yapıda yangın önleme ve söndürme sistemleri de bir o kadar önemli olmaktadır. Yapı içinde yeterli miktarda temiz hava bulunması, gerekli alanlarda koku kontrolü yapılması gerekmektedir. Güvenlik sistemleri kendi içlerinde gelişmiş durumdadır. Yapı içinde bakteri kontrolü, sıhhi tesisat sistemlerinin hijyenik, sessiz ve verimli çalışması, bina yönetim sistemlerinin uygulanabilmesi, birer uzmanlık dalı haline gelmiştir (Okutan, 1998:131).

High Tech uygulaması olan bir binada, en önemli tesisat sistemi isıtma ve havalandırma sistemidir. Günümüzdeki anlayış genel bir iklimlendirme sistemi yerine, her küçük bağımsız mekânda, o mekânı kullanan kimsenin kontrol edebileceği çevre koşulları oluşturmaktır. Bu durumda kullanıc1, kendisini en rahat durumda hissedecek ve işinde daha verimli olacaktır. Genel mekânlarda ise yerel koşullar çok değiştirilmeden tanımlanan bazı iklimlendirme standartları en az müdahale ile gerçekleştirilmektedir. Her iki tür mekân için de iklimlendirme değerleri devamlı olarak ölçülmekte ve standartın altına düşen değerler küçük müdahalelerle tekrar gereken yere çıkarılmaktadır. Bir tür optimizasyon uygulaması olan bu işlem belli bir konfor düzeyini sağlamak için en az enerji sarfını gerektirmekte ve bilgisayar teknolojisi ile yürütülmektedir (Eşsiz, 1997: 15-16).

Binanın cephelerini oluşturan cam kabuk da benzer biçimde tasarlanmaktadır.

Çeşitli cephelerdeki aydınlanma, ısınma ve soğuma durumlarına bağlı olarak bu kabuk renk değiştirebilmekte, içerideki sıcaklığı koruyabilmek için gerektiğinde dışarıdan ısı almakta veya gerekirse diş ortama karşı iyi bir yalıtım oluşturmaktadır. Bütün bu davranışlar yine sürekli ölçümler sonucu cam kabuğun bilgisayar teknolojisi ile değiştirilen özelliklerine bağlı olarak düzenlenmektedir. Bu suretle iç mekânlarda maksimum konfor sağlanabildiği gibi “enerji korunumu”. ilkesine de uyulmuş olunmaktadır (Özgen,1995: 332-334).

\subsection{Sağlıklu Hava ve Gaz Temizleme Sistemi}

High Tech yapılarda geliştirilmiş mekanik sistemlerle, üstün bir hava ve gaz temizleme sistemi uygulanmaktadır. Temizlenen hava tekrar yapida kullanılabilmektedir. Nitekim çevrenin korunması, enerji tasarrufu, sağlıklı bir hava ve gaz temizleme sistemi, doğal ışık kullanımı ve bina otomasyonu gibi olgular, yeni performans kriteri gibi karşımıza çıkmakta ve ileri teknoloji kullanılarak çözüm getirilebilecek bu sorunlar, giderek High T e c h mimarinin kapsamı içine girmektedir. 


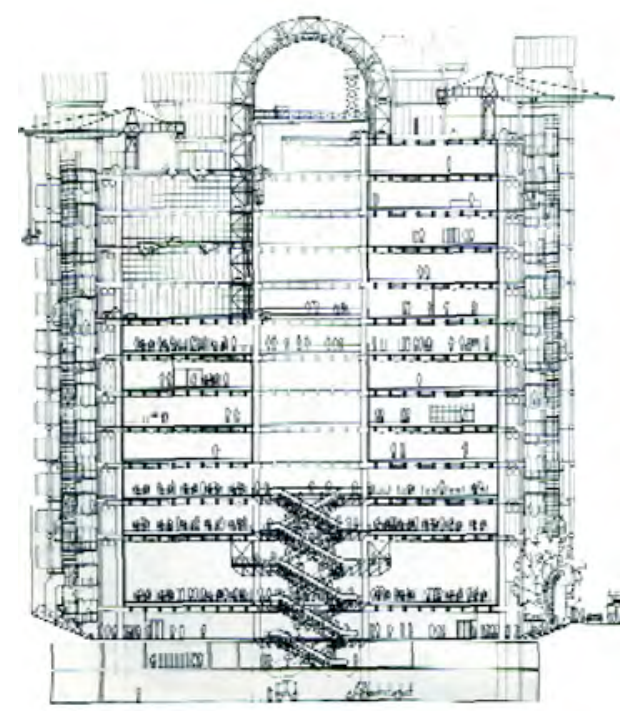

9

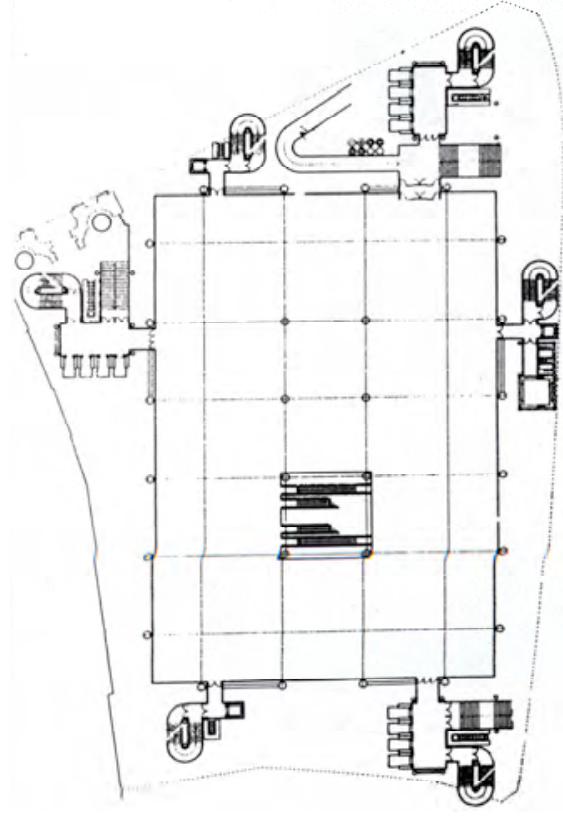

10

Şekil: 9

Lloyds Binasinin kesiti Şekil: 10

Lloyds Binasinin planı yerini alacak gibi görünmektedir. Deprem bölgelerinde uygulama örneklerini gördüğümüz High Tech yapılar, üzerinde inşa edildikleri arazinin olumsuz koşullarını ortadan kaldıran kontrol mekanizmalarına sahiptirler. Bu şekilde, deprem ve tayfunların sık görüldüğü böl-

\subsection{Doğal Işık Kullanımı}

High Tech yapılarda doğal ışıktan maksimum derecede yararlanılır. Doğal ışığın, atriumun üzerini örten cam kafeslerle zemin ve diğer katlarda mekânın derinliklerine kadar alınması sağlanır. Bunu gerçekleştirmede, çatıya yerleştirilen ve gün 1şı̆̆ını yapının içine yansıtan büyük aynalar önemli rol oynar. Hong Kong Bankası'nın orta holü, binanın dışına yerleştirilmiş, 24 parçadan oluşan, gün 1şığını iç mekâna alan ve güneşin hareketine göre şekil değiştiren bir ayna sistemi ile aydınlatılmaktadır. Daha sonra bu ışık, holün üzerine yerleştirilmiş uygun açılara göre konulmuş sabit aynalar yardımı ile orta holü aydınlatmaktadır. Bu durumda hole bakan katların iç kısımları da dış kısımda olduğu gibi oldukça güçlü bir 1şıkla aydınlatılmış olmaktadır. Doğal ışı̆̆ı yapının derinliklerine götürme çalışmaları yapan Norman Foster ve Richard Rogers tasarladıkları tekniğgi, 1977'de Paris'teki Centre Pompidou'da Sanat Merkezi'nde ve 1978 'de İngiltere Norwich'te Sainsbury Center'da kullanmışlardır (Eşsiz ,1997:17).

\subsection{Aktif ve Pasif Kontrol Mekanizmalart}

Verimlilik ve teknolojinin rasyonel kullanımı High Tech mimarinin geleceğine damgasını vuracak ve yüksek teknoloji içeren buluşların bolca ve savrukça gelerde yapılacak yapıların, bu tür doğal afetler karşısında zarar görmesi önlenmiş olmaktadir.

\section{High Tech Mimari Örnekleri}

High tech mimarinin önde gelen örneklerinden biri Richard Rogers’ın 1984‘de yapımı tamamlanan Lloyds Binası, diğeri de Norman Foster'1n 1985'de yapımı tamamlanmış olan Hong Kong Bankası'dır. Bu binalar yukarıda anlatılan özelliklerin hepsini içermeleri bakımından önemlidir.

\subsection{Lloyd's Büro Binast -Londra}

Londra'nın merkezinde yeralan yapı, High Tech mimarinin tüm özelliklerini taşımaktadır. Yapı, "ara sokak" diyebileceğimiz çok dar bir cadde üzerinde bulunmaktadır. Önündeki küçük meydancık bu yapının daha iyi algılanmasına yardımcı olmaktadır. Zeminde 68.4 x $46.8 \mathrm{~m}^{2}$ alan kaplayan binaya Pompidou'daki gibi içeri gömülmüş bir giriş katından girilmektedir. Onun üzerinde iki kat yüksekliğindeki "room" bulunmaktadır. "Room" katı birbirine yürüyen merdivenlerle bağlanırken, diğer katlara merdivenler, asansör ve servis kulelerinden ulaşım sağlanmaktadır. Giriş katının devamında atrium açık olarak yükselmektedir; ayrıca bu alt katın atriuma bakan kısımları da cam ile kaplanmıştır. Yapı, adeta bir makinenin verdiği imajı yakalamaya çalışmıştır. 9x3 $\mathrm{m}^{2}$ büyüklüğündeki W.C. kapsüllerinin prefabrike oluşları, cephede özel elemanların görünüşü, asansörlerin dışarıdan bakıldığında adeta süzülür gibi katlar arasında dolaşması ve yine merdiven kovaları, dışarıda, bir makinanın adeta binaya dönüşmüş halini yansıtmaktadır. (Şekil 9-10).

Binanın dışında 6 servis kulesi vardır. Bunların dört adedi dar kenarda, diğerleri uzun kenarda bulunmaktadır. Uzun aksta bulunan kuleler arasındaki alan çelik 
konstrüksiyon ile geçilmiş ve böylece binanın ortasında ferah bir atrium alanı oluşturulmuştur. Yapı, yanında bulunan tarihi yapıya tamamen zit malzemesi ve görünüşü itibariyle bir makineyi yansıtmasıyla değişik zamanları ilginç bir şekilde biraraya getirmektedir (Buchanan, 1986:41).

\section{Metal ve cam Richard Rogers}

mimarlığının karakteristik malzemeleridir, bu nedenle Lloyds'da temel malzeme olarak çeliğin kullanılması sürpriz olmamıştır. Konstrüksiyon, çelik-beton taşıyıcılardan oluşturulmuştur. Bunlar $105 \mathrm{~cm}$ çapında olup birbirlerine U profiller ile bağlanarak, prefabrike kelepçeler ile tutturulmuştur. Döşeme konstrüksiyonu $55 \mathrm{~cm}$ yüksekliğinde 180x180 cm 1zgara betonarme kirişli çerçevelerden oluşturulmuştur.

Düşey iki taşıyıcı arasına konmuş altı adet diyagonal taşıyıcı, rüzgâr yüküne karşı binanın stabilitesini sağlamaktadır. $\mathrm{Bu}$ diyagonaller, beton giydirilmiş kalın çelik borulardan oluşmaktadır. Servis kuleleri, hazır çelik beton konstrüksiyon olarak sonradan ilave edilmiştir. Bunların birleşim noktaları vida ile tespit şeklindedir. Bu yöntem, bina yapım süresini kısaltmak için seçilmiştir.

Çatı yapım sisteminde beton plaklar ile çerçeve birbirine geçmiş durumdadır. $\mathrm{Bu}$ yöntem konvansiyonel sayılmamakla birlikte, kolay bir montaj yöntemidir ve esnekliği güvenli bir şekilde çözerek sistemin kendi içindeki rijitliğini sağlamıştır.

Yapıda 1.,3. ve 5. kulelere gelen yatay yükler, çapraz çerçeveler ve yapının döşemeleri aracılı̆̆ıyla, zemin ve çatı arasında düşey kiriş gibi davranan diştaki çift diyagonal kuşaklı kolonlara aktarılmaktadır. 2.,4. ve 6. kuleler için ise,

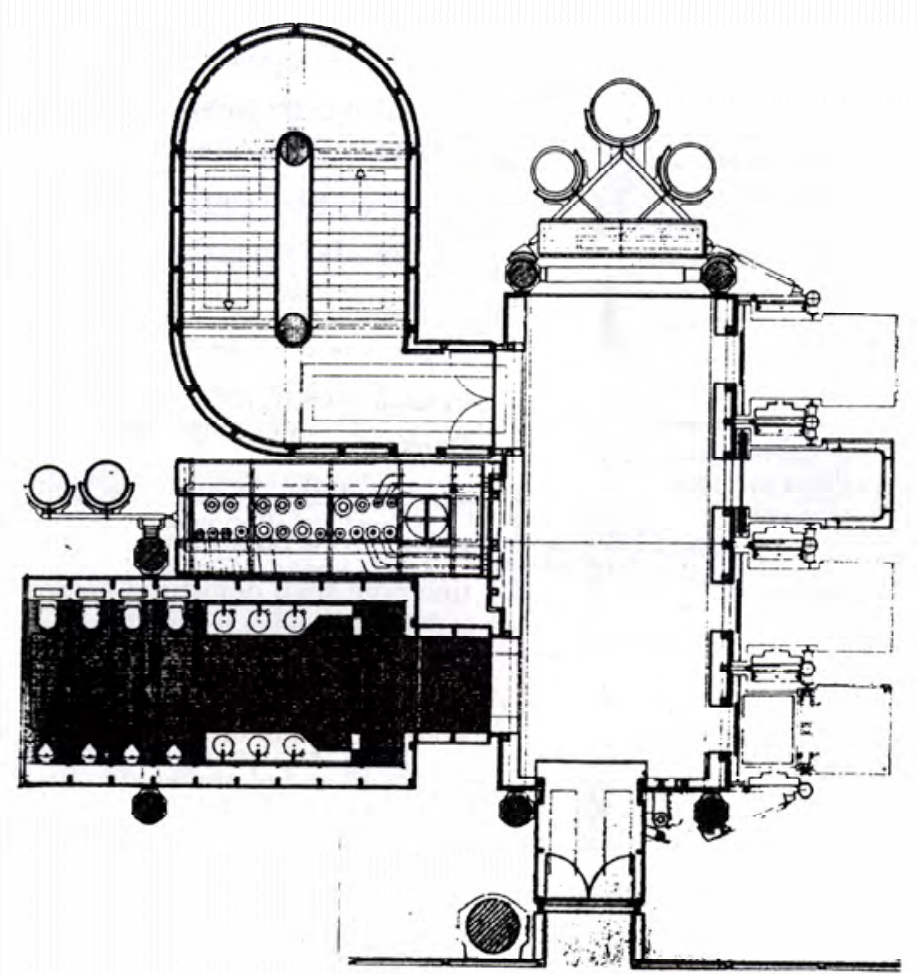

prekast beton asansör şaftı, düşey kiriş gibi davranmaktadır. Kulelerdeki diğer bütün kolon ve kirişler sadece düşey yükhücreleri leri taşımak için tasarlanmıştır. 6 satellite kulesinin üstü, metal giydirme cepheli 4 büyük kutu hücresiyle bitirilmiştir. Uzaktan bakıldığında binanın görünüşünü etkileyen, yapıya ağır ve nispetlerin dışına çıkmış bir görüntü veren 3 kat yüksekliğindeki bu hücreler, asansör motorları, tanklar ve servis odalarını içermektedir. Yapılan ilk çalışmalarda bu kısımlar daha küçük ve yapıya şık bir görüntü verecek şekilde tasarlanmışken, bu büyüklük final yapının gereksinimini karşılayacak kapasitede olmadığı için, sonuçta mekanik tesisatların yeraldı̆̆ büyük yapılmıştır (Anon, 1986: 14-18 ).

High Tech yapılarda kutu hücreler özellikle servis bölümlerinde, tuvalet modülleri olarak kullanılmaktadır. Lloyd's Binası'nın 33 tuvalet hücresi, fabrikada kontrol 


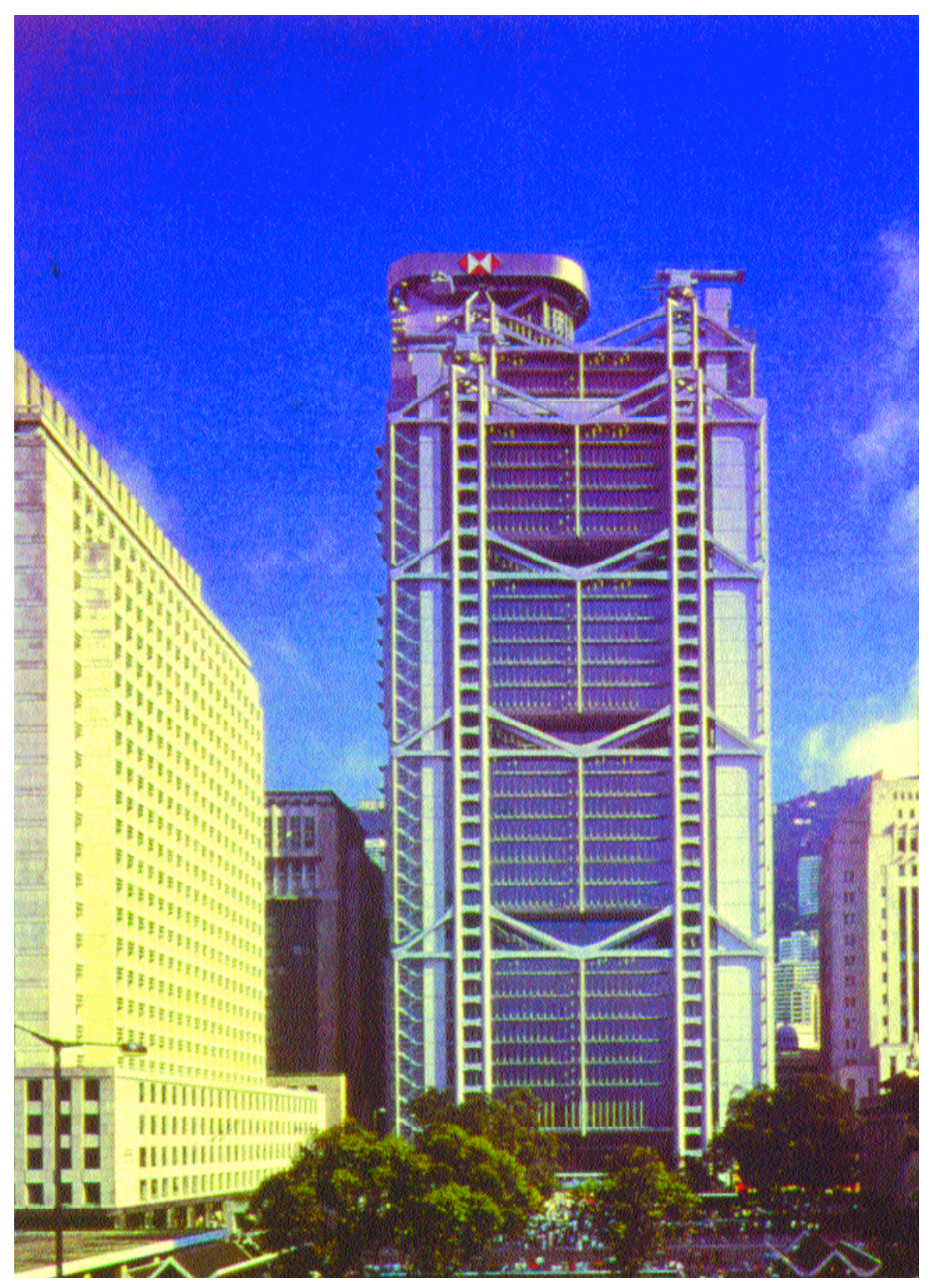

Şekil: 12

Hong Kong Bankasi, Norman Foster, Hong Kong, 1985 altında, yerine takılmaya hazır halde yapılmışlardır. Bir arıza anında kolayca değiştirilip yerine yenisinin takılmasına imkân tanıyan bu hücreler, mekanik servislerin çoğunun yapının dışında olması nedeniyle, döşemeye zarar vermeden, değiştirilebilmektedirler (Şekil 11).

Servis kulelerinin konstrüksiyonu kutu hücrelerin tespiti bakımından önemlidir. Prekast yuvarlak formlu elemanlar çeliktir, üstleri betonla kaplanmıştır. Kolonların betonlanmasının nedenlerinden biri, bu kolonların yangın kesici özelliği göstermesini sağlamaktır. Servis kulelerinin içinde tuvalet hücrelerinin yanısıra, asansörler, yangın merdivenleri ve tesisat boruları yer almaktadır (Russel,1985:72).

Yap1 genelde prefabrike elemanlardan oluşmuştur. Prekast kolonlar, döşeme ile birleşim yerlerinde yine prekast başlıklarından birleştirilmiştir. Giydirme cephenin dişında yeralan kolonlar, yatay ve düşey yükleri karşılamaları için yine prekast elemanlarla birleştirilmiştir. Kirişler, cephe kaplama yüklerini ve bölücü duvarları taşıyacakları için öngerilmeli yapılmış, böylece büyük sehim yapmaları önlenmiştir. (Şekil 15)

Servislerin döşeme boşluklarından geçmesi günümüzde çok yaygın kullanılmakta ve gelişmektedir. 1970 yılında ilk kez BMW Binası'nda uygulanan bu sistemin daha karmaşık şekli bu yapıda görülmektedir. Elektrik kabloları, telefon, bilgisayar hattı, havalandırma sistemi yükseltilmiş döşeme altında yeralmış ve döşeme panellerinde çıkış noktaları ile mekâna servis verilmiştir. Belirli döşeme panellerinden çıkan bu kablolar, herhangi bir arıza anında bütün sisteme ulaşılmasına imkân veren çıkarılıp takılabilir özelliklere sahiptirler. Yapının üzerinde bulunan vinçler cephenin temizlenmesinde kullanıldı ̆̆ gibi renkleri ve görüntüleriyle yapıya değişik bir etki vermektedir.

\subsection{Hong Kong Bankast-Hong Kong}

Hong Kong Bankası sadece Hong

Kong'un değil dünyanın en önemli bankalarından biridir. 1935 yılında ilk yapı inşa edildiğinde Kahire ve San Francisco arasındaki en yüksek ve ilk havalandırma sistemine sahip yapı olma gibi özellikleri taşımaktaydı. İki yılda tamamlanan eski yapı, banknotların ön yüzlerinde yeralacak kadar önemliydi (Şekil 12). 
1970'lerin ortalarına gelindiğinde yapının ihtiyaçlara cevap verememesi nedeniyle 1979 Haziranı'nda ABD, İngiltere, Avustralya ve Hong Kong'tan davet edilen firmalar yeni genel müdürlük binası için açılan yarışma nedeniyle Hong Kong'a geldiler. Eylül 1979'da Foster ve ekibi yarışmayı kazandı ve bugün Hong Kong'un ve günümüz mimarlığının önemli yapılarından biri olan bu binayı inşa etme fırsatını yakaladı. Banka Yönetim Kurulu, yeni yönetim merkezinin yapımını Foster'a verirken, mevcut arsaya göre en geniş kullanım alanına ve en geniş teknolojiye sahip, içi sonsuz derecede olanaklı ve 21. Yüzyıl'ın gereksinimlerine uyabilecek bir yapı istemiştir. Özellikle bankanın Genel Müdürü Michael Sandberg, Foster'dan binanın "en iyi biçimde" yapılmasını istemiş, maliyetin ise "ikinci planda" kaldığını söylemiştir. Çünkü bina, gücü, güveni ve teknik performansı temsil etmek zorundadır (Zunz, Glover,1986: 540-543).

Son yılların High Tech ürünü olan Hong Kong Bankası'nda geçmiş ile gelecek, geleneksel değerler ile teknolojik gelişmelerin içiçe ve birlikte kullanıldı ğı görülmektedir. Binada mekânsal özellikler, mekânın kuruluşu, mekânın bileşenleri, insanla ilişkileri, doluluklar ve boşluklar, işlevsellik, bütünün farklı konumlardan farklı biçimde algılanabilmesi gibi mekâna ilişkin değerler teknolojinin sunduğu olanaklarla sağlanmıştır (Ökten,1995:299).

\section{Binanın dış biçimi Hong Kong'un} geleneklerine bağımlı kalarak oluşturulmuştur. Yapının aşağı yukarı her bölümü farklı ülkelerde üretilmiş, getirilen parçalar Hong Kong'da birleştirilmiştir. Strüktürü oluşturan aksam İngiltere'den, camlar, alüminyum kaplamalar ve döşemeler Amerika'dan, ayna ve sabunluklar Japonya'dan, mermer kaplama bankolar İtalya' dan getirtilmiştir.

Hong Kong Bankası komşu yapılara nazaran daha hafif ve şeffaf bir yapıdır. Yapının üst katlarından atriuma bakıldığında, uçan payandalar ve tamamlanmamış görünüşüyle doğu penceresinin büyük şeffaflığı sanki Batı'nın katedrallerinden esinlenmiş havasını vermektedir. $50 \mathrm{~m}$ yüksekliğindeki bankanın atriumu tamamen Köln Katedrali'nin nefine benzemektedir. High Tech mimari, bir yandan en gelişmiş malzeme ve üretim biçimlerini, kısacası yüksek teknolojiyi kullanıp bir yandan da teknolojiyi görselleştirirken başlı başına mimari bir dil oluşturmuştur.

Hong Kong Bankası 20. Yüzyıl'ın modern yüksek bina teknolojisinin bir ürünüdür. Norman Foster'ın yapılarındaki en karakteristik özellik, mimarın malzemeler hakkında öğrendiği yeni teknikleri yapılarında uygulamasıdır (Eşsiz, 1997:1012). Hong Kong Bankası birçok teknik yeniliği bünyesinde taşımaktadır. Fakat önemli yenilikler, kullanılan teknoloji ile değil, metotla ilgilidir. Bankanın tasarımcıları bunu, "tasarımın gelişmesi" olarak tanımlamaktadırlar. Hazır bileşenler kullanmanın getirdiği teknik ve mali avantajları kullanmadan, müşterinin arzusunu yerine getirme yarışının nasıl sürdürüleceği önemli bir problemdir. Mimar, kendi ihtiyaçlarını fazla ya da az detaylı bir yolla basitçe ortaya koyar ve bunu, hazır tasarım ya da standart sistemlerin küçük uyarlamaları ile tamamlamaları için imalatçılara ve müteahhitlere bırakır. Foster ve ekibinin daha farklı bir çözümü vardır. Onların çözümüne göre tasarımın gelişimi endüstri ile mimarlığın ortak çalışmasıdır. 


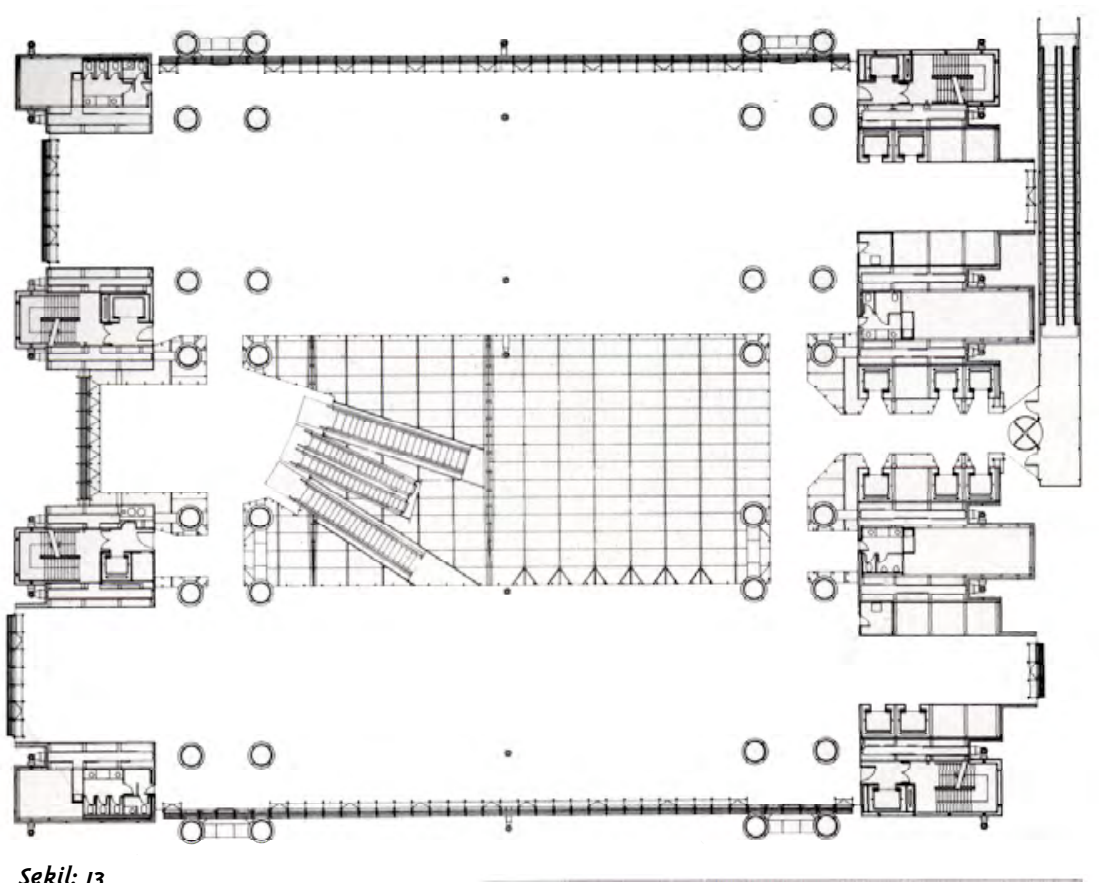

Hong Kong Bankasi, Birinci kat planı
Hong Kong Bankası'nda bu model test edilmiştir. Bankanın hemen herbir elemanı, fabrika kökenli uzmanların ortak çalışmasıyla, mimarların onayı alınana kadar, örnekler halinde tasarlanmış ve geliştirilmiştir. İmalatçılar mimarların yaratıcılığından ve projeye tümden bakışlarından yararlanırken, mimarlar da kendi geleneksel eğitimlerinde olmayan gelişmiş endüstriyel üretim metotlarının sağladığı olanakları görmeye başlayarak, ortak çalışmanın başarılı ürününü ortaya koymuşlardır (Okutan,1998; 132-133)

Mühendislik hizmetlerini Ove Arup ve ekibinin yaptığı 47 katlı Hong Kong

Bankası, ortasında atriumun bulunduğu iki bölümden oluşmaktadır (Şekil 13). Yapının tam ortasında yeralan 11 kat yüksekliğinde ve 1. kattan başlayan banka aktif servislerinin bulunduğu atrium, Wright'ın Larkin Binası'nda ortaya attı̆̆ı "mekânın şeffaflaştırılması" fikrinin daha da ileri bir anlamda yinelenmesidir. Avlunun aydınlığ ki özgün yarı saydam cam kaplama örtü, gündüz ışı̆̆ının yansıtılması ile işlevselliğin, estetikle bütünlüğün sağlanmasıdır. Bu anlamda bir araç olan teknolojinin amaca ulaşmak için en uygun şekilde kullanımı, bu yapıda görülmektedir. Burada mekânın anlamı, kullanılan malzemeden daha önemlidir. Mekânın boyutu, atmosferi ve kullanım değeri o mekânı belirleyen özelliklerdir. Malzeme ancak bir yan belirleyicidir; tasarlanan ve yaratılan mekânlar yaşanılan dönemlerin ürünleri olmalıdır. Bu doğrultuda Foster, tasarladığı yapının yaşadığı dönemin ürünü olmasına azami dikkati göstermektedir (Eşsiz 1997:157-167).

Yapının iç kısmında büro mekânları olarak hizmet verecek çok sayıda alan oluşturulmuştur ve bunları kendi içinde 1,2 veya 3 bölgeye ayırmış durumdadır. 3 adet olan iki kat yüksekliğindeki taşıyıcı bölgeler sosyal fonksiyona ve prestije hizmet vermektedir. Zemin kattaki açık plazanın, yukarısında, atriuma çıkan bölüm bir cam örtü ile kapatılmıştır. Böylece tayfun esnasında ortaya çıkan rüzgâr basıncının, girişten girerek bütün atriumu etkilemesi önlenmektedir. Binanın konstrüksiyonu asma sistem ile yapıldığ 1 için içerde yatay bir çekirdek doluluğuna ihtiyaç kalmamıştır ve böylece tamamen boşaltılmış bir zemin kat planı ve 11 kat yüksekliğinde merkezi, ferah bir atrium oluşturulmuştur. Zemini tümüyle boşaltılan, iki ana caddeden giriş ve geçiş sağlayan yapıda, 1. katta başlayan atriuma, muazzam uzunlukta iki yürüyen merdivenle ( $25 \mathrm{~m}$. uzunluğunda) giriş ve çıkış sağlanmaktadır. Binada yürüyen merdivenlerin sayıca bolluğu ayrıca göze çarpmaktadır. Bu konsept, asansör adedinden tasarruf, ayrica da uzun bekleme sürelerinin kısalmasını sağlamaktadır. 
Yüksek hızda çalışan asansörler, yapının batı bölümünde yeralmakta ve plaza seviyesi ile bütünleşmektedir. Ayrıca tasarlanan ek iki asansör, bankacılık servis bölümleri arasındaki ilişkiyi etkin bir şekilde sağlamaktadır. Boşluğun içinden yükselen yürüyen merdivenler işlevselliğin yanısıra plastik etkisi ile dikkatleri çekmektedir. Asansörlerin şeffaf olarak tasarlanması sayesinde, hareket halindeki kullanıcıların tüm mekânı farklı seviyelerden farklı biçimde algılaması düşünülmüştür.

Taşıyıcı sistem, dörderli çelik kolonlardan oluşmakta ve bunlar da her kat seviyesinde yatay kirişlerle birbirine bağlanmaktadır. Beş ayrı seviyede de; 11, $20,28,35$ ve 41 . kat seviyelerinde birbirine iki kat yüksekliğinde doğu-batı yönünde çapraz desteklerle, kuzey-güney yönünde kafes kirişlerle bağlanmaktadır. Binanın strüktürü, işlevselliği ve estetiğ ile ayrılmaz bir bütünlük göstermektedir. Bütün yapıyı taşıyan kulelerin herbiri kompozit 16.2 metrede 4 ana kolondan oluşmuş kare bir bölüm içindedir (Şekil 14). Planın temel elemanları, asansör şaftları ve lobiler batı kanadındaki vierendeel kuleler arasına tespit edilmiştir.Taşıyıcıları kaplanmış yapının strüktüründe, insanda merak uyandıran bir mantık dışılık vardır. Bankanın strüktürü de aynı prensiple çalışır. Merkezi askı taşıyıcılar, kompozit çelik anakirişten gelen yükleri ve metal döşemeyi taşırken, dıştaki askı taşıyıcılar kısmen daha hafif olan prefabrike servis modüllerini ve merdiven ünitelerini taşır. Merkezdeki dengelenmiş yük, iki düşey çaprazlanmış kolonda, bir ağacın dallarının gövdede neden olduğu gibi, bir eğilme oluşturmaktadır. Yükler yukarıdaki askılara bağlanarak ve oradan da çapraz bağlarla kolonlara ve yere iletiliyor gibi görünmektedir. Kolonlarlar arası $32 \mathrm{~m}$. net açıklık geçilmektedir (Şekil 15-16). Rüzgârda ve depremde yanal rijitliğin sağlanması önemli bir konudur. Hong Kong'da şiddetli kasırgalardan duyulan endişe depremlerinkinden fazladır ve tasarımı etkiler.

Mekânların ileriye dönük esnek hale getirilmesi fikri binanın tüm biçimini de belirlemiştir. Binanın ileriye dönük bir büyüme kapasitesinin oluşu, bitmemişlik hissi veren hafif asimetrikliği ve üst katların alt katlara göre geride inşa edilmeleri, yapının zaman içerisinde değişimlere açık olduğu fikrini yansıtmaktadır. Prefabrike elemanlar kullanılan yapı, gerektiğinde ek katlar ilâve edilebilecek durumdadır (Davery 1986:33-56).

Üstünde 36 kat bulunan atriuma gün ışı̆̆ını getirmek arzusu yapıya, ilginç bir buluş ve uygulama kazandırmıştır. Bina dışında yeralan bilgisayar kontrollü 480 adet cam aynadan oluşan "güneş küreği" güneşin hareketine göre değişim yaparak 1şınları, bina içinde atriumun tepesinde kalan 225 alüminyum aynadan oluşan sisteme yansitmakta, bu sistem de atriumu gizemli bir gün ışığı ile aydınlatmaktadır. Atrium ayrıca bilgisayar kontrollü akustik ve klima özelliklerine sahip, 1sı, ses ve 1şık denetimini yapmaktadır. Yıllık gün 1şı̆̆ının durumuna göre atriumun $1 s ̧ 1 \mathrm{k}$ ihtiyacı aynı olmak üzere içeriye eşit miktarlarda dağıtılmaktadır. Bu ışıklandırma sistemi dar açılı ve yüksek 1şıklandırma kuvveti ile 52 m yükseklikteki yeri aydınlatmaktadır. Bu tesisin kuruluşu Almanya'da gerçekleştirilmiştir (Davery, 1986:33-56).

Yapının klima sisteminin soğutulabilmesi için bol miktarda suya ihtiyaç vardı. Bunun denizden alınan su ile çözülebileceği düşünülerek, $11 \mathrm{~m}$ çapında, $50 \mathrm{~m}$ derinlikte
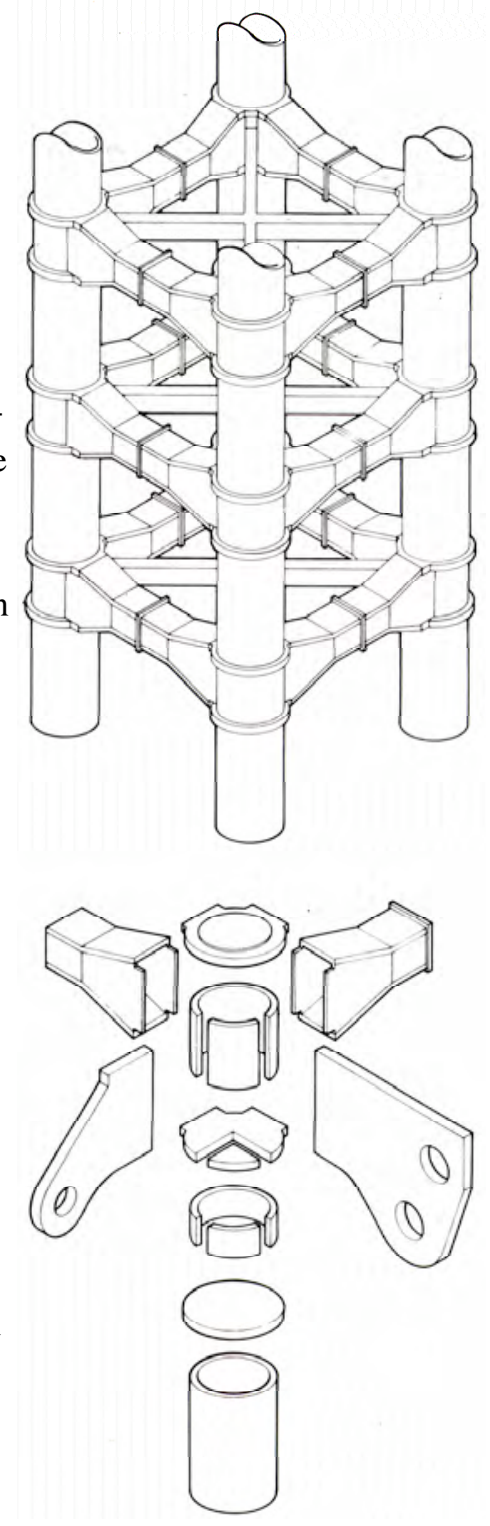


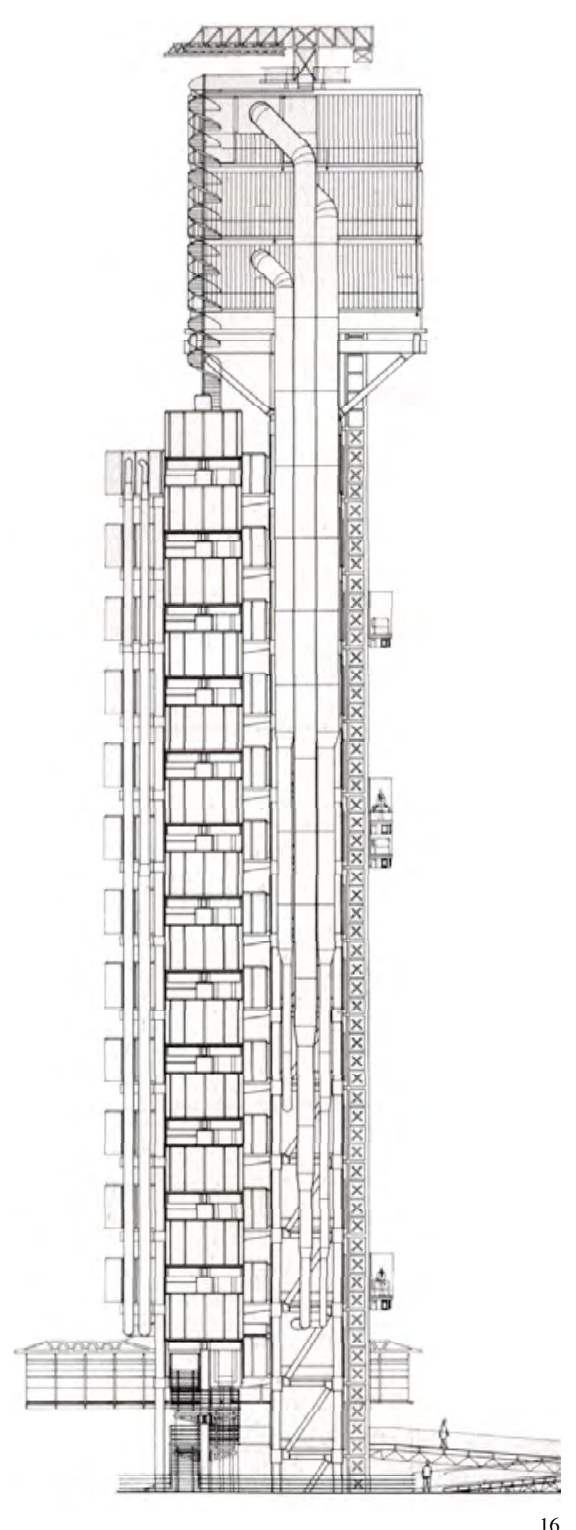

Şekil: is

Lloyd's Binasinin servis kulesi Şekil: 16

Hong Kong Bankasi'nin bina kesiti

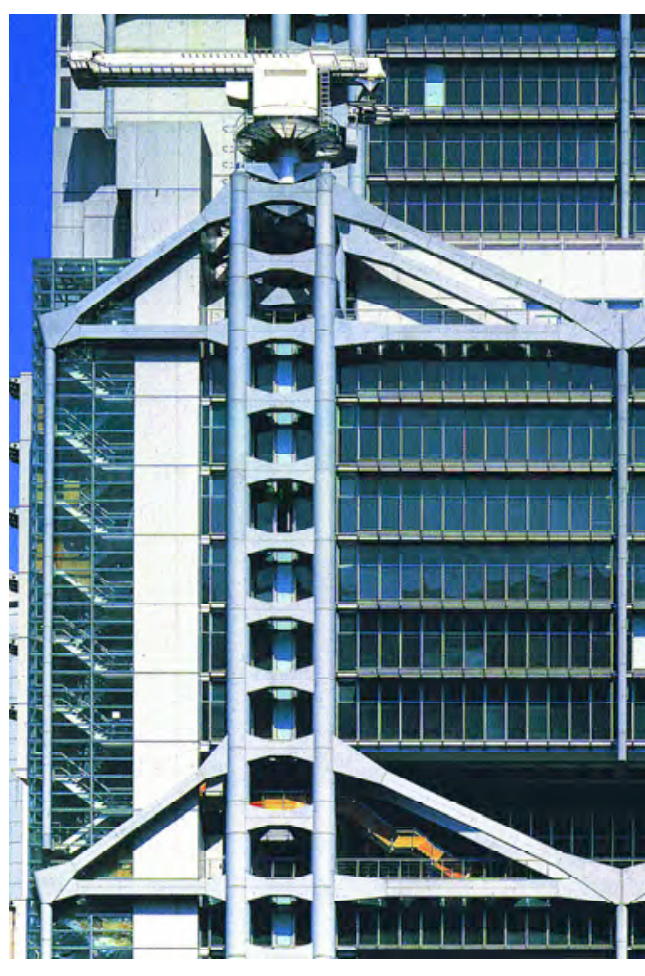

bir kuyu kazılmıştır. Bu kuyu 350 m.'lik bir tünelle sahile ulaştırılmış ve oradan, yapıya deniz suyu pompalanmıştır.

Hong Kong bankası özel bir duvar kaplamasıyla kaplanmıştır. Çeliğin kısmen seramik fiber tabaka ile "yangından etkilenmez" bir hale getirilmesi gerekmiştir. Düzgünlüğü koruyabilmek için ve binanın estetiği açısından her kolon, kiriş, payanda ve kafes kiriş köşegeninin alüminyumla kaplanması gerekmiştir. Yapı sekiz dikme ile ayakta durduğu için teoride mesnetler arasında $60 \mathrm{~mm}$.' lik sehimler olacaktır. Bunun da giydirme cepheye uyarlanması gerekmiştir. Ayrıca her katmanda güneş kırıcıların oluşturulması, asansörleri ve merdivenleri gizleyecek 1zgara duvarlar, düz olarak kaplanacak servis modülleri, 10 katlı atriumun sonundaki geniş katedral duvarları birer problem oluşturmaktaydı. Astropikal iklimli Hong Kong için alışılmadık şekilde, giydirme cephe çift kat verniklenmiştir. Bunun sebebi de, boşlukta

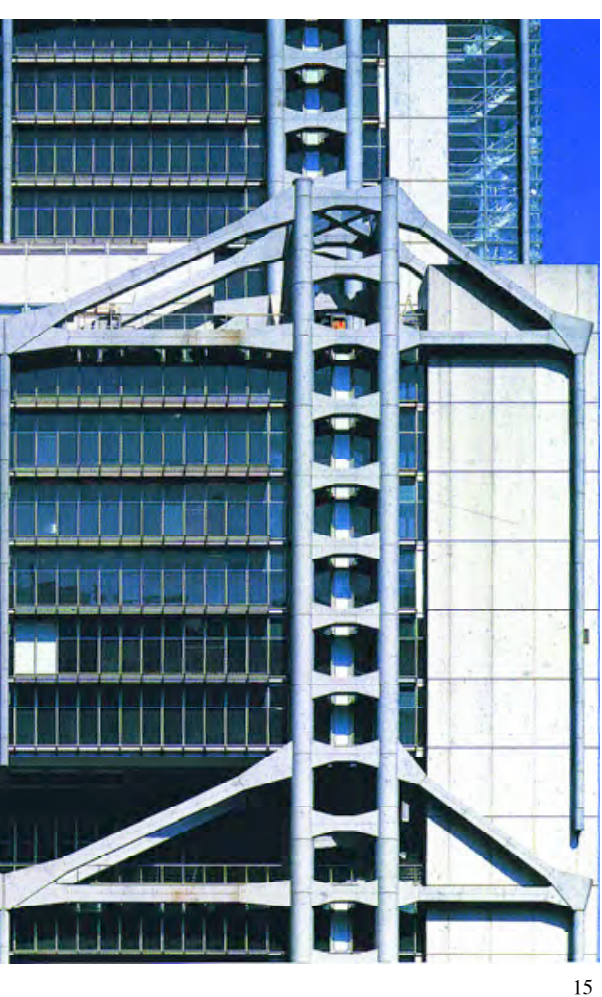

asılı delikli gümüş jaluziler kullanma isteğinden çok ısı kaybının önlenmesidir. Camların dış kaplaması 9 mm kalınlığında ve şeffaftır, içte ise $5 \mathrm{~mm}$. kalınlığında ve grimsi bir yeşil tonu uygulanmıştır .

Pencere temizliği ve rutin bakım her bir kattaki alüminyum ızgara şeklindeki yollarla yapılmaktadir. Konsollar, Foster'ın metal eşya tasarımlarını hatırlatan yuvarlak deliklerle delinmiştir. Bunlar ön cephede önemli bir yer teşkil etmektedir.

Binanın dış yapısındaki elemanların tasarımı oldukça karmaşıktır. Örneğin; "katedral duvarı" denilen kısımlar iki pencere arasındaki kedi yolları ile desteklenmiştir. Servis modülleri alüminyum panellerle kaplanmış, asansörler ve merdivenler yapı silikonu ile verniklenmiştir.

Binanın doğu ve batı bölümlerinde toplanmış, 139 tane tuvalet hücresi vardır. 
Binada bağlantıları ve konumları itibariyle birbirinden farkl1 7 tuvalet tipi bulunmaktadır. Bunlar birbirlerine 2 ya da 3 katlı çelik çerçevelerle yapılmış kaldıraçlarla bağlanmıştır.

Foster ve grubu yükseltilen panel döşemeyi icat etmemiş, ancak piyasadaki kataloglarda bulunan standart sistemlerden birini de tercih etmemiştir. Onlar yapımcılarla ortak bir çalışmaya girerek yeni bir sistem üzerinde çalışmışlardır. Döşeme sistemindeki ilk gereksinim esneklikti fakat, bütün "esnek" planların da bir sürü kuralları vardı. Bu nedenle, ızgaranın boyutları için yapılan çalışmalar sonucunda 1200x1200 mm'lik boyutlara karar verilerek, bu bölümlerde gerekli olan esneklik sağlanmış ve bağlantıların sayısı azaltılmıştır. Ancak bu aynı zamanda standart panel konstrüksiyonun destekler arasında uzanacak kadar güçlü olmadığını ve çok fazla ağır olduğunu da göstermiştir. Buna çözüm olarak da son zamanlarda uçak yapım endüstrisinde de sıkça kullanılan sağlam, hafif ve bükülebilir olan alüminyum kullanılmıştır.

1200x1200mm.'lik ebata sahip elektrikli aksam, iletişim ve havalandırma için oldukça geniş bulunduğu için, çalışma masalarının ve bölümlerinin rahat olması için 600 mm x 600 mm'lik daha küçük 1zgaralar tercih edilmiştir. Havalandırma çıkışları, yakınındaki insanları rahatsız etmesin diye spiral şeklinde tasarlanmış, bu da elektrik ve iletişimle ilgili bir üst tabaka elektronik ekipmanlarının kullanılmasına olanak vermiştir.

Toplam 52 katı olan yapının 47 katı zemin üstünde, 1 katı zeminde ve 4 katı da zemin altında yeralmaktadır. Ayrıca temel derinliği zemin altında $34 \mathrm{~m}^{2}$ ye kadar varmak- ta ve bu özelliği ile Hong Kong'taki en derin yeraltı yapısı durumunda olmaktadır. Bodrum katlarının derinliği 18.8 m.'yi bulmaktadır. Yapıda 3500 ton alüminyum kaplama, 1000 ton alüminyum döşeme, $32000 \mathrm{~m}^{2}$ isole edilmiş cam, $3000 \mathrm{~km}$ elektrik kablosu kullanılmıştır. Yapıda kullanılan strüktürel çeliğin ağırlığı 37000 ton, diğer çeliklerin ağırlığı ise 30000 tonu bulmaktadır. Yapının maliyeti 1.5 milyar DM'a malolmuştur. Bankanın verdiği paranın yarısı gümüş renkli köprü strüktürüne harcanmıştır(Lambot 1988:202, 245).

\section{Sonuç}

Geleceğin yapıları olarak nitelendirilen ve günümüzde giderek artan uygulamaları gözlenen High Tech yapıların ortak özellikleri aşağıda verilmiştir: Genelde, High Tech yapılar bitmemiş gibi gözükmekte ve ilave katlara olanak verecek şekilde inşa edilmektedir. $\mathrm{Bu}$ yapılarda ana malzemenin çelik olması geniş açıklıkların geçilmesine imkân vermektedir.

$\mathrm{Bu}$ tür yapılarda kullanılan malzemeler makina endüstrisinde kullanılan plastik, metal ve cam malzemelerdir. Bu şekilde makinayı oluşturan parçalar gibi bina da birtakım parçalara ayrılarak endüstrileşmektedir. "Açık sistem" diye nitelendirilen bu uygulamada, her parçanın ayrı fabrikalarda üretilip, binada yerine takılması söz konusu olmaktadır. Bunun en önemli örneği, bileşenlerinin her biri değişik ülkelerde üretilmiş Hong Kong Bankası'nda görülmektedir.

Yapılardan, değişen ihtiyaçlar göz önüne alındı ̆̆ında, zamanla değişime imkân verebilmesi istenmektedir. Mekânların 
servis, asansör veya merdivenlerle bölünmemesi için bunlar yapının dışına alınmışlardır. Bu şekilde yapıya hem makina estetiği verilmiş hem de mekâna esneklik sağlanmıştır. Yapının dışına alınan servis modülleri de fabrikada üstün teknoloji ile üretilerek binada yerine monte edilmektedir. Bu şekilde hızla gelişen teknoloji sonucunda, zamanla özelliğini yitiren ve çabuk arızalanan modüller yapıya zarar vermeden kolayca yenileri ile değiştirilebilmekte, eskileri de değişik yerlerde tekrar kullanılabilmektedir. Bu da yapı teknolojisinin önemli yeniliklerinden birisidir.

Burada esasları verilen High Tech ilkelerinin küreselleşmenin yarattığ 1 olanaklar kapsamında çok yakın bir gelecekte ülkemizde de uygulanması kaçınılmaz görünmektedir 1

\section{KAYNAKÇA}

Anon, (1986) "Lloyds of London", Baumeister, Kasım. Buchanan P. (1986) "Machines for Working in", Architectural Review, Ekim.

Çağlar, N., Utkutuğ, Z. (1995) "Mimarlıkta Çağın Ruhunu Yakalamak:Yüksek Teknoloji Yapıları", Bina Yapımında Güncel Yaklaşımlar Sempozyumu, MSÜ, İstanbul.

Davery, P. (1986) "Hong Kong Bank", Architectural Review, Nisan.

Davies, C. (1991) High Tech Architecture, Verlag Gerd Hatje, Stuttgart.

Eşsiz, Ö. (1997) İleri Teknoloji Yapıları ve Uygulama Örneklerinin İncelenmesi, Yayınlanmamış Yüksek Lisans Tezi, MSÜ Fen Bilimleri Enstitüsü, İstanbul.

Jencks C. (1990) The New Modern, Academy Edition, Londra.

Jenks C. (1988) Architecture Today, Academy Editions, Londra.

Kulaksızoğlu, E. (1995) "Mimarlıkta İleri Teknolojiler", Bina Yapımında Güncel Yaklaşımlar Sempozyumu, MSÜ, İstanbul.

Lambot, I. (1988) Norman Foster Associates, Buildings and Projects, Cilt: 1-2-3, Enst, Sohn, Hong Kong.

Okutan, M. (1998) "Modern Ofis Binaları ve Yapı Teknolojisi Uygulamaları", Arredamento Dekorasyon, Nisan.

Ökten, S. (1995) "High Tech Kavramı ve Ülkemizdeki Uygulama Olanakları", Bina Yapımında Güncel Yaklaşımlar Sempozyumu, MSÜ, İstanbul

Özgen, A., (1995) "Güncel ve Gelecek Yaklaşımlar: Binaların Yeni Çă̆ı̆”, Bina Yapımında Güncel Yaklaşımlar Sempozyumu, MSÜ, İstanbul.

Russel F. (1985) Richard Rogers Architects, Academy Editions, Londra.

Türel, G. (1995) "Yüksek Teknoloji Binalarının Kent İçinde ve Dışında Konut Olarak Kullanılmasının Getirdiği Problemlerin Belirlenmesi ve Çözüm Örneklerinin Geliştirilmesi", Bina Yapımında Güncel Yaklaşımlar Sempozyumu, MSÜ, İstanbul.

Zunz, J., Glover, M. (1986) "The Hong Kong and Shangai Bank Project", Lynn S. Beedle(der.) Advances in Tall Buildings, Van Nostrand Reinhold Company, New York. 